\title{
Evaluation of different plant powders as seed protectants against rice moth, Corcyra cephalonica Stainton
}

\author{
B. L. Meena ${ }^{1}$, K. L. Jeengar ${ }^{1}$, Bhim Singh ${ }^{2 *}$ and N. L. Meena ${ }^{3}$ \\ Department of Entomology, S.K.N. College of Agriculture, S. K. Rajasthan Agricultural University, Campus, \\ Jobner-303 329 (Rajasthan), INDIA \\ ${ }^{1}$ Present Address: Krishi Vigyan Kendra, Jhalawar-326 001, (Rajasthan), INDIA \\ ${ }^{2}$ College of Horticulture and Forestry, Jhalarapatan, Jhalawar-326 023, (Rajasthan), INDIA \\ ${ }^{3}$ Krishi Vigyan Kendra, Bundi, (Rajasthan), INDIA \\ *Corresponding author. E-mail: bhimsingh1@gmail.com
}

Received: July 27, 2015; Revised received: February 16, 2016; Accepted: May 30, 2016

\begin{abstract}
The present study was aimed to develop the eco-friendly and economic approaches to keep the stored food grains free from insect attack would be using the plant products as grain protectants. In the context of biological control as an alternative to chemical control, under laboratory conditions, different plant powders viz., dharak kernel and leaf (Melia azadirach L.), neem kernel and leaf (Azadirachta indica Adr. Juss), karanj kernel (Pongamia glabra), aak leaf (Calotropis procera Br.), datura leaf (Datura alba Nees.), citrus leaf (Citrus lemon L.), podina leaf (Mentha arvensis) and tulsi leaf (Ocimum sanctum L.) were compared, at three rate of application $(1.0,2.5 \mathrm{and} 5.0 \mathrm{~g}$ per $100 \mathrm{~g}$ seeds), as protectants against infestation of sorghum (Sorghum bicolor (L.) Moench) seeds by the storage pest Corcyra cephalonica Stainton. The larval period of test insect got progressively increased with the increase in dose level of different plant powders. The maximum (77.83\%) and minimum (37.83\%) reduction in adult emergence was observed in dharak kernel powder and tulsi leaf powder, respectively. The test insect developed on seeds treated with dharak kernel powder laid significantly $(P>0.5)$ minimum number of eggs (80.33 eggs/ female) followed by neem kernel powder (85.66 eggs/female). The dharak and neem kernel powders were found most effective in reducing the longevity of male (3.96 and 5.13 days) and female adults (4.63 and 4.97 days), respectively. The results suggest that these materials tested have the potential in the development of post-harvest protection technology against, C. cephalonica, the major pest of stored grains.
\end{abstract}

Keywords: Corcyra cephalonica, Egg viability, Plant powders, Seed protectants, Stored grains

\section{INTRODUCTION}

In India, post-harvest losses caused by the unscientific storage, rodents, insects, micro-organisms and moisture etc. account for about 10 percent of total food grains. Amongst the various stored grain insect-pests, rice moth, Corcyra cephalonica Stainton (Lepidoptera: Pyralidae) is a cosmopolitan in distribution and cause a serious damage to the stored grains (Pandey et al., 1985; Singh and Mishra, 1989; Patel and Patel, 2007; Yadav et al., 2011 ${ }^{\mathrm{a}}$ ). The excreta, exuviae and dead bodies also get mixed up in the food stuff, hence damage in both quantitative and qualitative loss. Hence, effective storage protection strategies are urgently required. Current control measures for the C. cephalonica included chemical insecticide, fumigation and biological control. These methods are expensive and cannot be afforded by the small-scale farmers in developing countries. Success achieved so far in making the stored products free from pests has been largely dependant on pesticides alone. Pesticides are the most powerful tool available for pest control. Despite these credentials, the long and indiscriminate use of pesticides has been found ecologically unsound. It has been owing to the man's tendency to substitute pesticides for effective bio-environmental controls rather than restrict their use to emergent situations, necessitating the concept of pest management in present format. One of the eco-friendly and economic approaches to keep the stored food grains free from insect attack would be using the plant products as grain protectants for managing the insect population in stored products. Controlling them with chemicals is a serious concern as it leads to environmental contamination and health hazards (Tillman and Mulrooney, 2000). To test the powders from different plants, we used doses of 1.0, 2.5 and $5.0 \mathrm{~g}$ per $100 \mathrm{~g}$ seeds, Every dose of plant powders were tested on different biological aspects of the insect in a constant temperature $\left(28^{\circ} \mathrm{C}\right)$ and relative humidity $(72 \% \pm 5)$. The interest in this kind of work is the search for plants that can be used locally as bio-pesticide for protection of this precious commodity. Use of naturally occurring or locally available plant materials to protect agriculture products against insect pests is an 
old-age common traditional practice in many parts of the world for medicinal purposes and in agriculture (Mukanga et al., 2010 and Khani et al., 2013). The principal advantage of botanicals is the farmers are able to provide their own protectants (Isman, 2008; Mukanga et al., 2010). Extracts from different plants have been known to possess insecticidal properties against a wide range of insect pests (Abdullahi and Muhammad, 2004; Pathak and Tiwari, 2010). Plants with insecticidal properties offer a cheaper sustainable alternative to synthetic insecticides, store design, fumigation and thermal distribution methods. They could be an abundant source of locally available pest control agents that can be grown at the village level. The insecticidal specificity of some plant extracts and their lack of negative impacts on the food and the environment make them ideal candidates for incorporation into an integrated pest management strategy.

Exact quantities of botanicals from these plants that give optimum insecticidal effects are unknown. It is thus desirable to quantify the amount of the plant derived materials that provide adequate protection against insect pests and to determine how these affect insect behaviour, growth and reproduction (Jilani, 1992 and Meena and Bhargava, 2005). Equally, plant species that are found to be effective and popular locally with the farmers need to be subjected to safety testing, at least involving basic toxicological studies (Jilani, 1992). The principal advantage of botanicals is that farmers are able to provide their own protectants (Isman, 2008). There are encouraging reports on the use of certain indigenous plant products as grain protectants (Pandey et al., 1985; Jacob and Sheila, 1990; Bhargava, 1997; Sharma and Bhargava, 2001; Pathak and Tiwari, 2010; Yadav et al., 2011 ). The use of powders aromatized with essential oils, has a twofold advantage due to combined effects of mechanical action, blocking the insect's articulations (Ramaswamy et al., 1995; Mukanga et $a l ., 2010)$. In case of rice moth, C. cephalonica, meager information is available in literature regarding the efficacy of indigenous plant materials. Plants with insecticidal properties offer a cheaper sustainable alternative to synthetic insecticides, store design, fumigation and thermal distribution methods. They could be an abundant source of locally available pest control agents that can be grown at the village level. The insecticidal specificity of some of the plant extracts and their lack of negative impacts on the food and the environment make them ideal candidates for incorporation into an integrated pest management strategy. The purpose of our tests is the comparative study of the biocidal effects of powders of different plants on different biological parameters of the test insect. Under the present investigation, therefore, many plant products have been evaluated to find out their effectiveness against $C$. cephalonica pest.

\section{MATERIALS AND METHODS}

The experiment was conducted under laboratory conditions in the Department of Agricultural Zoology and
Entomology, S.K.N. College of Agriculture, Jobner campus of Rajasthan $\left(75^{\circ} 28^{\prime}\right.$ East longitude, $26^{\circ} 05^{\prime}$ North latitude). The eggs were obtained from Biocontrol Research Laboratory, Pest Control (India) Ltd., Bangalore. One C.C. (measuring in cubic centimeter which is containing approximately 16000-18000) eggs were released in $3 \mathrm{~kg}$ of broken sorghum grains. The culture was maintained in culture box of glass jars containers lined with black folded thick paper on the sides and blotting paper at the bottom. These glass jars were kept at $28 \pm 1^{\circ} \mathrm{C}$ and $70 \pm 5$ percent relative humidity. The chamber was covered with double layer of muslin cloth after releasing freshly emerged active adults. Most of the eggs were laid between the double layer of muslin cloth from where these were collected daily with the help of a soft brush and kept in separate petri dishes. The time and date of egg laying were recorded in order to select the eggs of known age that ensured continuous supply of eggs needed for the present study.

The powder of different plant products viz., dharak kernel and leaf (Melia azadirach L.), neem kernel and leaf (Azadirachta indica Adr. Juss), karanj kernel (Pongamia glabra), aak leaf (Calotropis procera $\mathrm{Br}$.), datura leaf (Datura alba Nees.), citrus leaf (Citrus lemon L.), podina leaf (Mentha arvensis) and tulsi leaf (Ocimum sanctum L.) were prepared by drying them in shade and then grinding them in electric grinder to get fine powder. The powder was sieved through 60 mesh sieve. Powders of all the plant products were mixed with seeds at the rate of $1.0,2.5$ and $5.0 \mathrm{~g}$ per $100 \mathrm{~g}$ of grains (w/w). For mixing the powder with seeds, $500 \mathrm{~g}$ grains were placed in a plastic bag $(25 \times 20 \mathrm{~cm})$ and desired amount of powder was added to it; each treatment was replicated thrice. The bag was then held from both the ends and shaken horizontally for $5 \mathrm{~min}$ utes to ensure through mixing. An aliquot from the powder mixed sample was used for the experimentation in each treatment. Untreated grains were used as control. Twenty five newly hatched larvae were released in the plastic container containing treated food. The observations recorded were larval period, pupal period, ovipositional response, reduction in adult emergence, fecundity, egg viability and longevity of adults. The larval period was worked out by recording the date of releasing newly hatched larvae and date of formation of silken web and the period between web formation and adult's emergence was considered as pupal period on treated food with different doses of test compounds. For recording the fecundity and ovipositional period of adult, which emerged from the larvae developed on treated food, were kept in separate jars for egg laying. The total number of eggs laid by each female was counted daily till the death of female in each treatment. For egg viability, a random sample of 50 eggs was taken from each replication and placed in separate container. The eggs hatched or unhatched were counted with the help of binocular microscope. The longevity of male, female adults and total number of 
Table 1. Effect of powdered plant products on larval period of C. cephalonica.

\begin{tabular}{|c|c|c|c|c|c|c|c|c|c|c|c|c|c|}
\hline \multirow[b]{2}{*}{$\begin{array}{l}\text { Dose (Parts } \\
\text { per } 100 \text { parts } \\
\text { of grain w/w) }\end{array}$} & & \multicolumn{12}{|c|}{ Larval period (days)* } \\
\hline & $\begin{array}{l}\text { s } \\
\text { rts } \\
\text { w) }\end{array}$ & \multirow{2}{*}{$\begin{array}{l}\begin{array}{l}\text { Dharak } \\
\text { kernel } \\
\text { powder }\end{array} \\
39.00\end{array}$} & \multicolumn{2}{|l|}{$\begin{array}{l}\text { Neem } \\
\text { kernel } \\
\text { powder }\end{array}$} & $\begin{array}{l}\text { Dhara } \\
\text { k leaf } \\
\text { powder }\end{array}$ & \multirow{2}{*}{$\begin{array}{l}\begin{array}{l}\text { Karanj } \\
\text { kernel } \\
\text { pow- } \\
\text { der }\end{array} \\
35.66\end{array}$} & \multirow{2}{*}{$\begin{array}{l}\begin{array}{l}\text { Neem } \\
\text { leaf } \\
\text { powder }\end{array} \\
36.33\end{array}$} & \multirow{2}{*}{$\begin{array}{l}\begin{array}{l}\text { Aak } \\
\text { leaf } \\
\text { pow- } \\
\text { der }\end{array} \\
37.00\end{array}$} & \multirow{2}{*}{$\begin{array}{l}\begin{array}{l}\text { Datura } \\
\text { leaf } \\
\text { powder }\end{array} \\
35.66\end{array}$} & \multirow{2}{*}{$\begin{array}{l}\begin{array}{l}\text { Citrus } \\
\text { leaf } \\
\text { powder }\end{array} \\
35.00\end{array}$} & \multirow{2}{*}{$\begin{array}{l}\text { Podina } \\
\text { leaf } \\
\text { powder }\end{array}$} & \multirow{2}{*}{$\begin{array}{l}\begin{array}{l}\text { Tulsi } \\
\text { leaf } \\
\text { pow- } \\
\text { der }\end{array} \\
34.00\end{array}$} & \multirow{2}{*}{$\begin{array}{l}\begin{array}{l}\text { Mea } \\
\text { n }\end{array} \\
36.87\end{array}$} \\
\hline 1.0 & & & 37.66 & & 37.00 & & & & & & & & \\
\hline 2.5 & & 44.33 & 43.33 & & 42.33 & 41.66 & 38.66 & 40.00 & 40.66 & 37.33 & 36.66 & 37.00 & 40.83 \\
\hline 5.0 & & 48.66 & 47.00 & & 46.00 & 48.00 & 42.00 & 43.66 & 43.00 & 39.33 & 39.00 & 38.33 & 42.87 \\
\hline \multirow{5}{*}{$\begin{array}{l}\text { Mean } \\
\text { Control }\end{array}$} & & 44.00 & 44.89 & & 41.78 & 41.78 & 39.00 & 40.22 & 39.78 & 37.22 & 36.78 & 36.44 & \\
\hline & & & & $\mathrm{Em}+$ & C.D & at $5 \%$ & C.V & & & & & & \\
\hline & Treatm & & & .33 & 0.9 & & & & & & & & \\
\hline & Dose & & & .18 & 0.5 & & 2.49 & & & & & & \\
\hline & Treatm & ent x Dose & & .57 & 1.6 & & & & & & & & \\
\hline
\end{tabular}

* Data based on 75 individuals (Three replications of 25 in each).

adults emerged from treated food with different concentrations/doses of test compounds, were recorded. The response of the test insects in the treated food were corrected using the modified Abbott's formula i.e. 100 (Number of insects in control - Number of insects in treatment)/ (Number of insects in control). The data obtained on various characters/ parameters were subjected to analysis of variance technique applicable for completely randomized design (CRD). The level of significance used in ' $\mathrm{F}$ ' test was $\mathrm{P}=0.05$ where ever $\mathrm{F}$ calculated was significant, critical difference values were calculated for treatment comparisons. The values obtained in percentages were transformed in to angular values and subjected to analysis of variance (ANOVA).

\section{RESULTS AND DISCUSSION}

Mixing of different plant materials with grains for the protection of insect pest constitutes one of the age old and indigenous practices adopted by the farmers, particularly in developing and under developed countries. Different plants are known to possess insecticidal properties and as such they have been used in protecting the grains against the damage of number of stored grain pests in different parts of country according to local availability of such materials. Many workers (Miah et al., 1993; Zibokere, 1994; Pandey and Singh, 1997; Patel and Patel, 2002; Meena and Bhargava, 2005; Righi Assia et al., 2010; Yadav et al., 2011 Pathak and Tiwari, 2012) have used products from several plant species for the protection of stored grains from insect pests.

Effect on larval period: When the newly hatched larvae were fed with treated food with test compounds in the present study, all the doses $(1.0,2.5$ and $5.0 \mathrm{~g}$ per $100 \mathrm{~g}$ seeds) of different plant powders were significantly better at 5 percent level in enhancing the larval period of test insect over control. The larval period of test insect got progressively increased with the increases in dose level of all tested compounds. The maximum duration of larva observed on seeds treated with neem kernel powder (44.89), which was at par with dharak kernel powder (44.00) shown in Table 1. These findings are in agreement with the results obtained by Chander and Ahmed (1986), Pandey et al. (1985), Jhansi Rani (1984) and Khan and Thakare (1997) who reported that larval period of one week old Corcyra larvae was significantly enhanced at 5 percent level when fed on grains treated with neem seed powder at 1.0 percent. This increase in the larval period is certainly due to antifeedent effect of plant products (Pandey et al., 1985; Veeranki and Reddy, 2004). This finding is in close conformity with the findings of Pathak and Tiwari (2010a) who reported that the larvicidal and pupicidal effects of neem leaf on the third instar larvae of Corcyra cephalonica Stainton. Veeranki and Reddy (2004) reported that custard apple seed powder, neem leaf, seed kernel powder and inert dusts (attapulgite and palygorskite) as effective treatment against $C$. cephalonica and $S$. cerealella, also support the present findings. Tiwari and Tiwari (2008) observed that diatomaceous earth formulation at 0.02 percent checked $93.8,98.1,100.0,100.0,100.0$ percent progeny of $R$. dominica, S. oryzae, T. castaneum, S. cerealella and $C$. Cephalonica, respectively. Pathak and Tiwari (2010b) reported controlled $100 \%$ larval mortality of C. cephalonica with neem seed extract at $0.11 \%$ active ingredient (a.i.).

Effect on pupal period: In the present investigation, results obtained as regard to pupal period in different doses i.e. 1.0, 2.5 and $5.0 \mathrm{~g}$ per $100 \mathrm{~g}$ seeds and all tested compounds which mentioned in material and methods, were at par at 5 percent level with the control. Hence, the plant powders had no effect on pupal period, when the newly hatched larvae were developed on food treated with different plant powders (Table 2). The present investigations corroborate with that of Pandey et al. (1985) who reported that neem kernel and neem leaves powders at the rate of 1.0, 2.5 and 5.0 


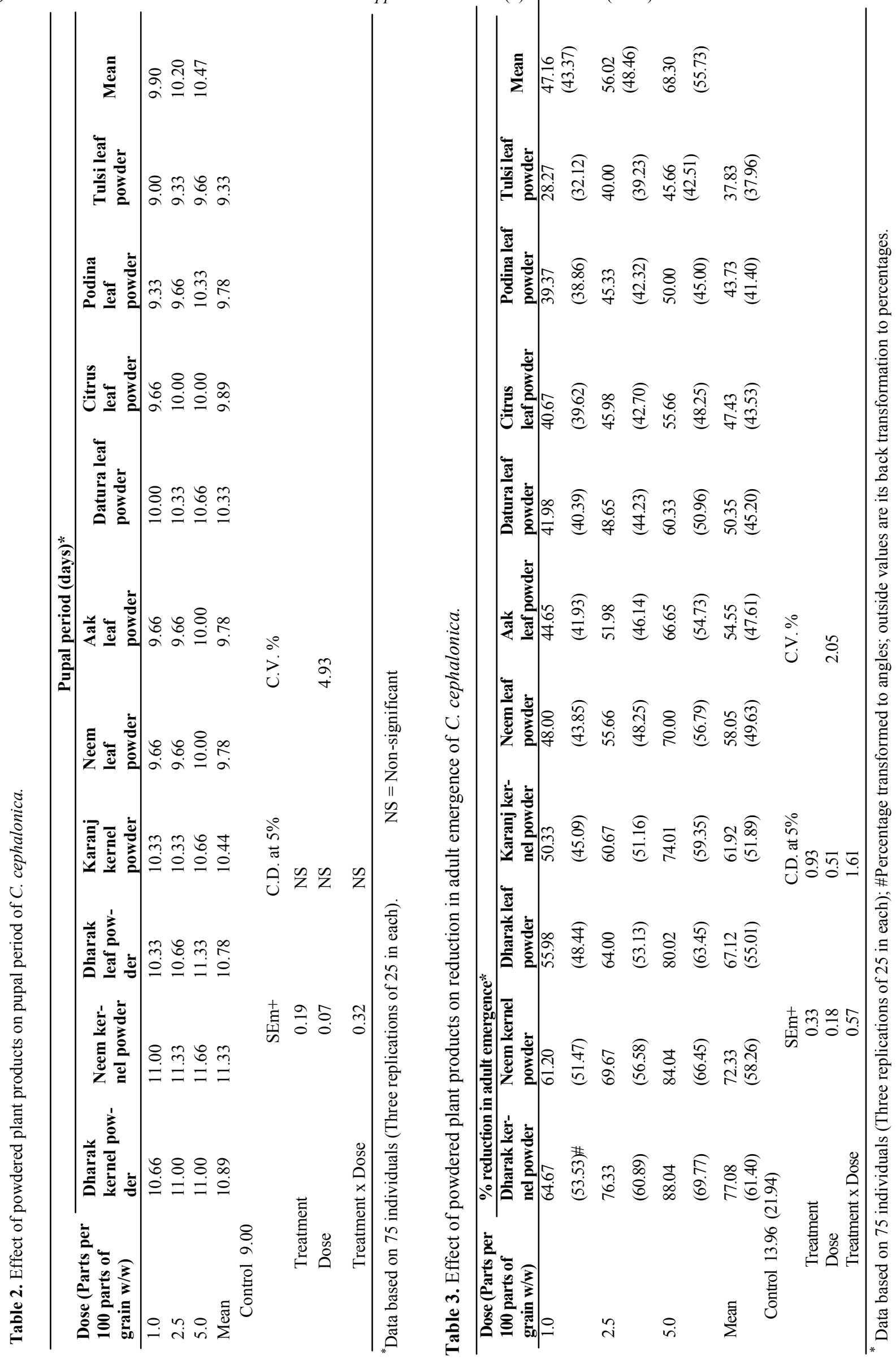


Table 4. Effect of powdered plant products on egg viability of C. cephalonica.

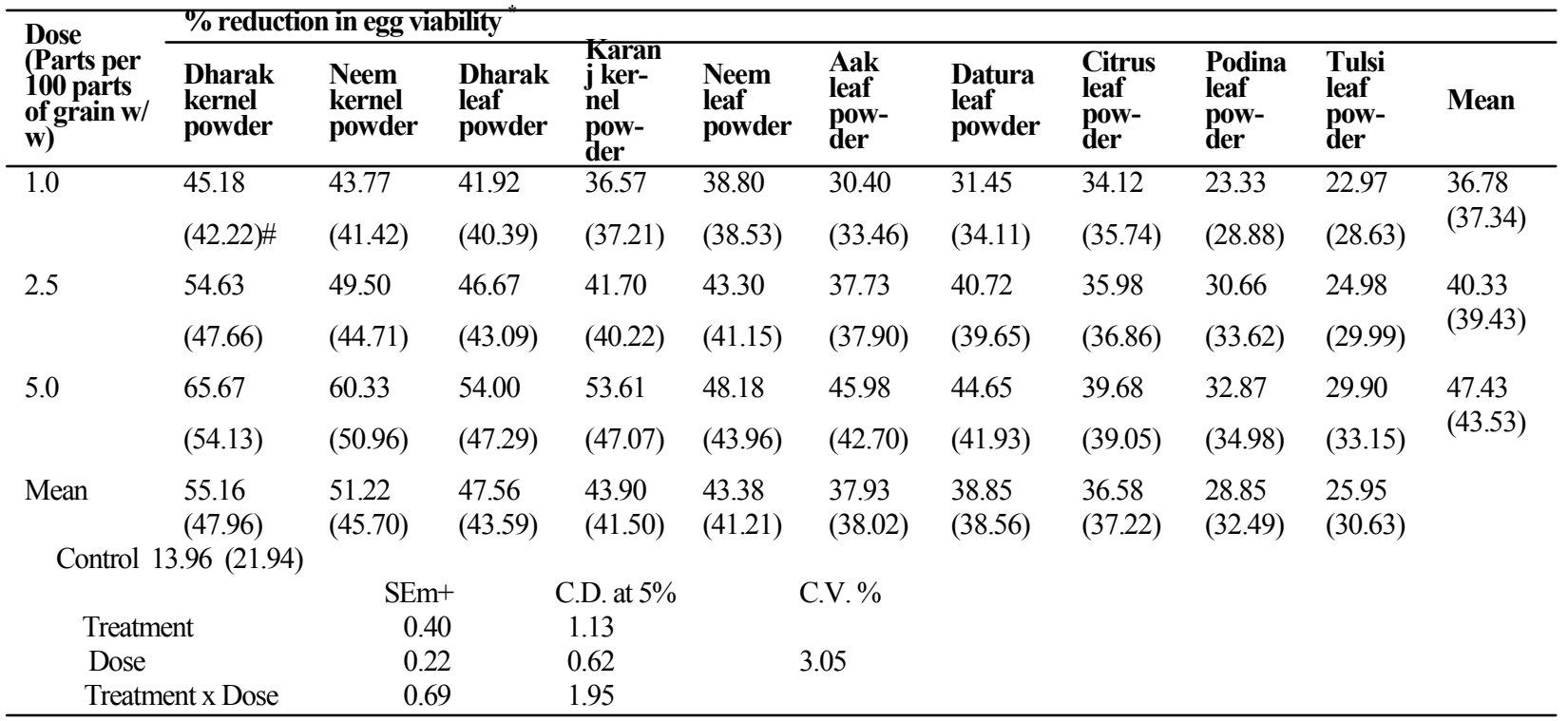

*Data based on 150 eggs (Three replications of 50 in each); \# Percentage transformed to angles; outside values are its back transformation to percentages.

Table 5. Effect of powdered plant products on ovipositional period of adult of C. cephalonica.

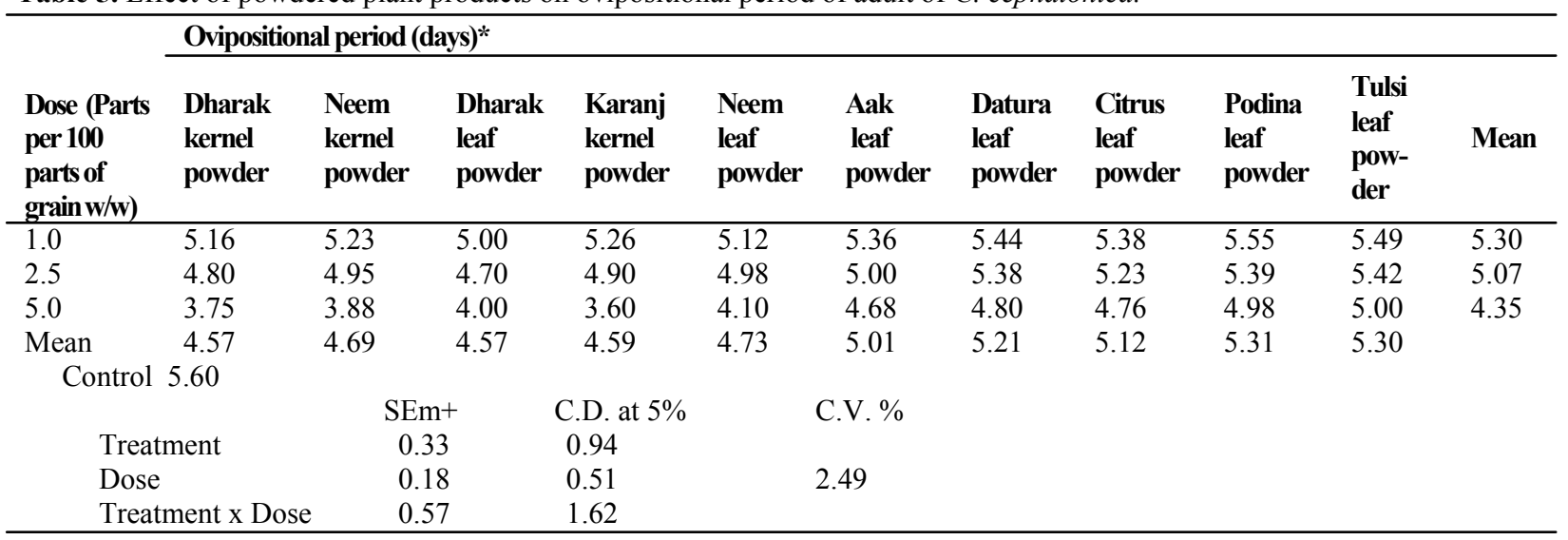

*Data based on 150 eggs (Three replications of 50 in each);\# Percentage transformed to angles; outside values are its back transformation to percentages.

ercent (w/w) had no effect on pupal period of $C$. cephalonica but Pathak and Tiwari $\left(2010^{\mathrm{b}}\right)$ observed larvicidal and pupicidal effects of neem seed extract at $0.11 \%$ (a.i.) on the third instar larvae of C. cephalonica.

Effect on adult emergence: It is apparent from the data that all the doses of plant powders tested were found to be significantly superior at 5 percent level in reducing the adult emergence over control. In the present investigation, the maximum reduction in adult emergence was observed in the treatment of dharak kernel powder (77.08) followed by neem kernel (72.33), dharak leaf (67.12), karanj kernel (61.92), neem leaf (58.05), aak leaf (54.55), datura leaf (50.35), citrus leaf (47.43), podina leaf (43.73) and tulsi leaf powder (37.83) are shown in Table 3. The present findings are in conformity with Jhansi Rani (1984) who found poor adult emergence in C. cephalonica when wheat flour was treated with neem kernel powder 2.0 percent (w/w). Pandey et al. (1985) also found that mixing of neem oil, kernel, cake, leaves and flowers with wheat seed at the rate of $0.1,1.0,5.0(\mathrm{w} / \mathrm{w})$ caused less percent adult emergence in $C$. cephalonica, support the present findings. Senguttuvan et al. (1995) also showed that neem leaf powder was effective in controlling the rice moth, $C$. cephalonica in groundnut kernels and pods under both artificial and natural conditions. Such type of findings was also reported by Singh and Srivastava (1980) in R. dominica when seed kernel powder mixed with wheat grain at the rate of 1.0, 2.5 and 5.0 percent $(\mathrm{w} / \mathrm{w})$. The percent reduction in adult emergence was 72.33 in neem kernel, 61.92 in karanj kernel and 58.05 in neem leaf, these results The present findings can be compared with those of Khan and Thakare (1997) who observed adult emergence was significantly reduced at 5 percent level when lar- 
Table 6. Effect of powdered plant products on fecundity of adult of $C$. cephalonica.

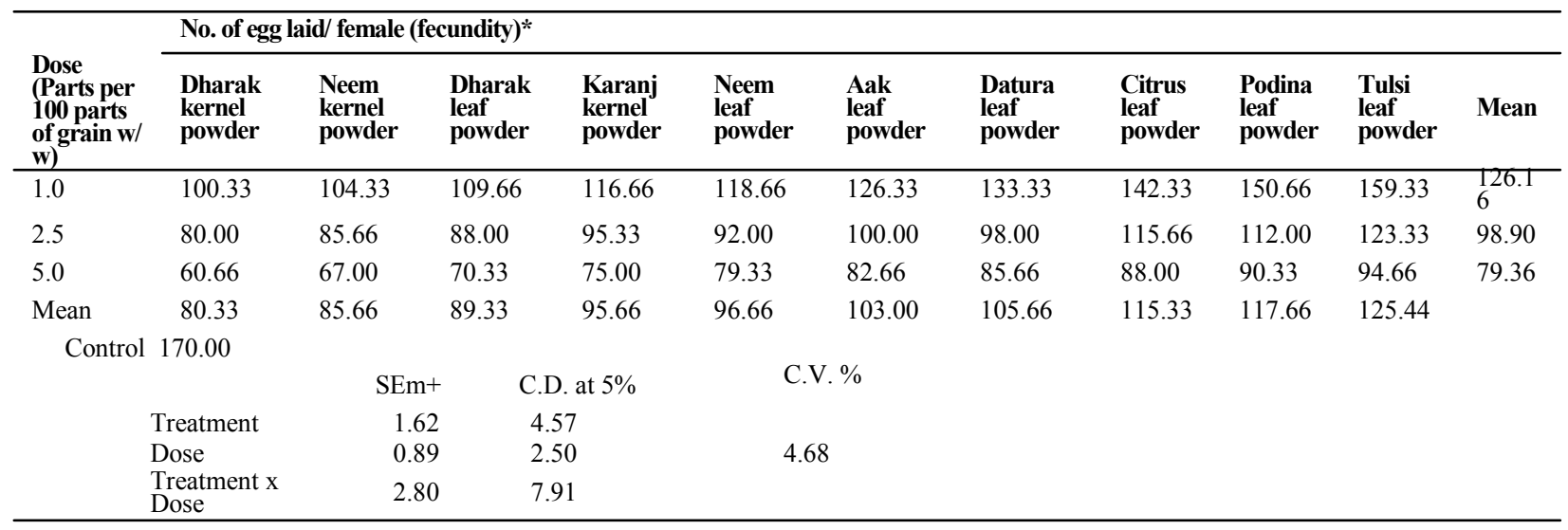

* Data based on 75 individuals (Three replications of 25 in each).

vae of $C$. cephalonica were exposed to grains treated with karanj, neem and castor oils $(0.5$ and $0.1 \%)$. Patel and Patel (2002) observed mixing of Neem and eucalyptus leaf powder at 2 percent and mustard oil at 0.5 percent were interfere with adults emergence, development period and growth index of the pest as well as weight loss of grains.

Effect on ovipositional period: In the present investigations, all the doses of different plant powders were significantly better at 5 percent level in reducing the oviposition period of test insect.

The minimum ovipositional period were observed in dharak kernel powder (4.57), which was at par with dharak leaf (4.57), karanj kernel (4.59), neem kernel (4.69) and neem leaf powder (4.73), while podina leaf powder (5.71) was proved least effective (Table 4). The present findings. are in conformity with Patel and Patel (2007), Mukanga et al. (2010), Pathak and Tiwari $\left(2010^{\mathrm{a}}\right)$, Khani et al. (2013), Shukla and Tiwari (2012) who found that neem seed and kernel extract, karanj kernel extract, guava and other plant products at the rate of $0.1,0.5,0.1,2.5$ and $5.0 \mathrm{~g} / 100 \mathrm{~g}$ seeds were effective against immature stages of $C$. cephalonica and other stored grain pests.

Effect on fecundity: In the present investigations, all the doses of different plant powders were significantly better at 5 percent level in reducing the egg laying capacity of test insect over control. The test insect developed on seeds treated with dharak kernel powder laid significantly minimum at 5 percent level number of eggs (80.33) over rest of treatments are given in Table 5 . The results of present investigation get corroborated with the observations of Khan and Thakare (1997) and Patel and Patel (2002) who reported that the adult emergence and egg laying capacity were significantly reduced when larvae of $C$. cephalonica were exposed to grains treated with karanj, neem and castor oils $(0.5$ and $0.1 \%$ ). . This reduction in fecundity may be attributed the toxic effect of the tested all plant powders in the experiment, the fine powder may also cause physical injury and block the spiracles, thereby affecting the normal physiology of the insects. Deterent and inhibi- tion on egg hatchabilities of citrus leaf powder on oviposition of $C$. maculates was reported by DonPedro (1985) and insecticidal action of neem seed acetone extract against the life cycle stages of $C$. cephalonica was reported by Pathak and Tiwari (2012), which support the present findings.

Effect on egg viability: All the doses (1.0, 2.5 and 5.0 $\mathrm{g} / 100 \mathrm{~g}$ seeds) of different plant powders were significantly better at 5 percent level in reducing the egg viability over control. The maximum (55.16) and minimum (25.95) reduction in egg viability were observed in dharak kernel powder and tulsi leaf powder, respectively (Table 6). Pandey et al. (1985) and Meena and Bhargava (2010) reported significant reduction in egg hatchability of $C$. cephalonica by the treatments of neem kernel powder and neem leaf powder at the dose level of $1.0 \mathrm{~g} / 100 \mathrm{~g}$ seeds, which support the present findings.

Effect on longevity of male and female adults: The effect of powdered leaves and kernels on the longevity of both adults of test insect was also observed in the present study. It is apparent from the data that the longevity of male and female adults gradually decreased with the increase in dose level of the treatments. Assessing the results of different plant powders, it was observed that the dharak kernel powder and neem kernel powder were the most effective in reducing the longevity of male and female adults (Table 7). Not much work is available on the effect of plant powders and on the longevity of male and female adults, however, Pandey et al. (1985), Khan and Thakare (1997) and Jain and Kumar (2001) found significant effect at 5 percent level of neem kernel powder and neem leaf powder on the longevity of male and female adults of C. cephalonica, which support the present findings. Pacheco et al. (1995) and Rajapakse and Vanemden (1997) have also demonstrated the effectiveness of treatment with neem, soybean and castor oils at the rate of 0,5 and $10 \mathrm{ml} / \mathrm{kg}$ seeds different oils against Callosobruchus maculates in reducing longevity and egg lying without affecting the germination of seeds, which support the present findings. Yadav et al. (2011) 
also found effective of different botanical pesticides like neem, karanj, castor, tulsi as both powder and oil form on the development of $C$. cephalonica., support the present findings.

Effect of plant powders on germination of sorghum seeds: In the present study, the effect of ten plant powders on germination of sorghum seeds revealed that no significant harmful effect was observed after 0,90 and 150 days of treatment. It indicated that there was no adverse effect of any dose of all plant powders on the germination of sorghum seeds at any interval. The present observations are in agreement with those of Prakash et al. (1984), Yadav and Bhatnagar (1987) and Chiranjeevi (1991) who found no adverse effect of different plant powders on germination of different grains. Pacheco et al. (1995) and Rajapakse and Vanemden (1997) have also demonstrated the effectiveness of treated with different plant products oils against Callosobruchus maculates in reducing longevity and egg lying without affecting the germination of seeds, support the present findings.

\section{Conclusion}

The present study concluded that different plant powders viz., dharak kernel and leaf (Melia azadirach L.), neem kernel and leaf ( $A$. indica Adr. Juss), karanj kernel (P. glabra), aak leaf (C.s procera Br.), datura leaf (D. alba Nees.), citrus leaf (C. lemon L.), podina leaf (M. arvensis) and tulsi leaf $(O$. sanctum L.) were compared, at three rate of application $(1.0,2.5$ and $5.0 \mathrm{~g}$ per $100 \mathrm{~g}$ seeds), tested as natural organic insecticide as well as grain protectants have the potential in development of post-harvest protection technology against C. cephalonica, the major pest of stored grains. The kernel and leaf powders of these plants were tested for their effect on the biology of C. cephalonica such as larval period, pupal period, ovipositional response, reduction in adult emergence, fecundity, egg viability and longevity of adults. The maximum (77.83) and minimum (37.83) percent reduction in adult emergence was observed in dharak kernel powder and tulsi leaf powder, respectively. Leaf powders suppressed the emergence of $C$. cephalonica populations in stored food grains. The reproduction potential was reduced but not completely inhibited. The effect was observed to be plant specific and dose related. Dharak kernel, neem kernel and leaf powder showed excellent reproduction and growth inhibitory effect. The mean percent reduction in egg viability ranged from 25.95 to 55.16 percent and 36.78 to 47.43 percent in different doses and treatments, respectively. The repellency effect of the powders was sustained throughout the study period. In general, the amounts and toxicity of the compounds in the leaf, kernel powders will depends on the maturity of the plants, the season (temperature, photoperiod, hygrometry) and the geographical and pedological conditions. Besides exhibiting the repellency, antifeeding and reproduction inhibition effects, the kernel and leaf extract exhibited vapour and con- 
tact toxicity on $C$. cephalonica. The presence of toxicants and growth inhibitors in these plants suggest good potential for their use in storage pest management especially farm stored grain. It is recommended that other doses and other plants should be used later to try and produce a range of organic insecticides that can be used at any time when the pest occurs.

\section{REFERENCES}

Abdullahi, Y.M. and Muhammad, S. (2004). Assessment of the toxic potentials of some plants powders on survival and development of Callosobruchus maculates. African Journal of Biotechnology, 3: 60-64.

Bhargava, M.C. (1997). Effect of some plant extracts on reproductive potentiality of Corcyra cephalonica Stainton (Lepidoptera: Pyralidae). Integrated Pest Management in Agriculture (eds) Bharad, G.M., Bonde, R.S., Nimbalkar, S.A. and Sarode, S.V., pp. 349-353.

Chander, H. and Ahmed, S.M. (1986). Effect of some plant materials on the development of rice moth, Corcyra cephalonica (Staint.). Entomon, 11: 273-276.

Chiranjeevi, C.H. (1991). Efficacy of some indigenous plant materials and ashes on the percentage of damaged grains, percentage of protection and viability of green gram seed infested by pulse beetle, Callosobruchus chinensis (L.). Bulletin of Grain Technology, 29: 84-88.

Don-Pedro, K.N. (1985). Toxicity of some citrus peels to Dermestes maculates Deg. and Callosobruchus maculates Febr. Journal of stored Product Research, 21: 3134.

Isman, M. (2008). Botanical insecticides: for richer, for poorer. Pest Management of Science, 64: 8-11.

Jacob, S. and Sheila, M.K. (1990). Treatment of green gram seeds with oils against the infestation of the pulse beetle, Callosobruchus chinensis L. Plant Protection of Bulletin, 42: 9-10.

Jain, K.L. and Kumar, V. (2001). Efficacy of neem against the rice moth, Corcyra cephalonica (Stainton). National Conference: Plant Protection- New Horizons in the Millennium, Udaipur, Abst., pp. 50.

Jhansi Rani, B. (1984). Studies on the biological efficacy of deoiled neem (Azadirachta indica A. Juss.) kernel against stored grains pests infesting wheat seed. Indian Journal of Entomology, 27: 160-164.

Jilani, G. (1992). Botanicals and Pheromones in IPM p. 5057 in. BALOCH, U.K. (ed.) Integrated Pest Management in Food Grains. FAO/ PARC. Islamabad, Pakistan.

Khan, M.I. and Thakare, H.S. (1997). Effect of selected plant products and entomopathogenic bacteria on development and control of rice moth, Corcyra cephalonica Stainton. Integrated Pest Management in Agriculture (eds) Bharad, G.M., Bonde, R.S., Nimbalkar, S.A. and Sarode, S.V. pp. 291-303.

Khani, M., Awang, R.M., Omar, D. and Rahmani, M. (2013). Toxicity, antifeedant, egg hatchability and adult emergence effect of Piper nigrum L. and Jatropha curcas L. extracts against rice moth, Corcyra cephalonica (Stainton). Journal of Medicinal Plants Research, 7 (18): 1255-1262.

Meena, B.L. and Bhargava, M.C. (2005). Effect of different plant powders on the reproductive potentiality of rice moth, Corcyra cephalonica Stainton. Agricultural Sci- ence Digest, 25: 103- 106.

Meena, B.L. Bhargava, M.C. (2010). Effect of plant powders on reproductive potential of Corcyra cephalonica Stainton (Lepidoptera: Pyralidae) on sorghum seeds. Journal of Insect Science, 23: 441-446.

Miah, M.R.U., Elias, M., Torofder, G.S., Islam, B.N., Sardar, M.A. and Karim, M.A. (1993). Evaluation of local plant material against the pulse beetle (Callosobruchus chinensis L.) on chickpea. Bangladesh Journal of Zoology, 21: 151-153.

Mukanga, M., Deedat, Y. and Mwangala, F.S. (2010). Toxic effects of five plant extracts against the larger grain borer, African Journal of Agricultural Research, 5 (24): 3369-3378.

Pacheco, A.I., DE Castro, F., Paula, D. and Lourencao, A. (1995). Efficacy of soy bean and castor oils in the control of Callosobruchus maculates (F.) and Callosobruchus phaseoli in stored chickpeas (Cicer arientinum). Journal of Stored Product Research, 19: 57-62.

Pandey, N.D., Pal, K., Pandey, S., Tripathi, R.A. and Singh, Y.P. (1985). Use of neem, Azadirachta indica A. Juss as seed protectant against rice moth, Corcyra cephalonica Stainton II- Effect on fecundity, fertility and longevity of adults. Bulletin of Grain Technology, 23: 265-268.

Pandey, N.K. and Singh, S.C. (1997). Effect of neem bark powder on infestation of pulse beetle, Callosobruchus chinensis Linn. in stored chickpea. Indian Journal of Entomology, 59: 161-163.

Patel, R.A. and Patel, B.R. (2002). Evaluation of certain plant products as grain protectants against the rice moth, Corcyra cephalonica Staint in stored rice. Pest Management and Economic Zoology, 10: 121-124.

Patel, R. A. and Patel, B. R. (2007). Comparative biology of rice moth, Corcyra cephalonica Stainton. Journal of Plant Protection and Environment, 4: 14-19.

Pathak, C.S. and Tiwari, S.K. (2010) ${ }^{\mathrm{a}}$. Toxicological effects of neem Azadirachta indica A. Juss leaf powder against the ontogeny of Corcyra cephalonica (Staint.) (Lepidoptera: Pyralidae). Journal of Biopesticides, 3: 617-621.

Pathak, C.S and Tiwari, S.K. (2010) ${ }^{\mathrm{b}}$. Toxicity of neem seed (Azadirachta indica A. Juss, Meliaceae) extract against immature stages of rice-moth, Corcyra cephalonica (Staint.) (Lepidoptera: Pyralidae). Journal of Applied Bioscience, 36: 173-177.

Pathak, C.S. and Tiwari, S.K. (2012). Insecticidal action of neem seed (Azadirachta indica A. Juss) acetone extract against the life-cycle stages of rice-moth, Corcyra cephalonica staint. (Lepidoptera: Pyralidae). World Journal of Agricultural Sciences, 8: 529-536.

Prakash, A., Pasalu, I.C. and Mathur, K.C. (1984). Evaluation of plant products as grain protectants in paddy storage. Indian Journal of Entomology, 1: 2027.

Rajapakse, R.H.S. and Vanemden, H.F. (1997). Potential of four vegetables oils and ten botanical powders for reducing infestation of cowpeas by Callosobruchus maculates, C. chinensis and C. rhodesianus. Journal of Stored Research, 33: 59-68.

Ramaswamy, S.B., Sch, S., Monroe, W.A. and Goire, I. (1995). Ultrastructure and potential role of integumentary glandular cells in adult male and female Callosobruchus subinnotatus (Pic) and C. maculates (Fabricius). International Journal of Insect Morphol- 
ogy, 24: 51-61

Righi-Assia, A.F., Khelil, M.A., Medjdoub Bensaad, F. and Righi, K. (2010). Efficacy of oils and powders of some medicinal plants in biological control of the pea weevil (Callosobruchus chinensis L.), African Journal of Agricultural Research, 5 (12): 1474-1481.

Senguttuvan, T., Kareem, A.A. and Rajendran, R. (1995). Effect of plant products and edible oils against rice moth, Corcyra cephalonica Stainton in stored groundnuts. Journal of Stored Product Research, 31: 207-210.

Sharma, K.C. and Bhargava, M.C. (2001). Ovicidal effect of some growth disrupting compounds on rice moth, Corcyra cephalonica Stainton (Lepidoptera: Pyralidae). Indian Journal of Applied Entomology, 15: 24-28.

Shukla, S. and Tiwari, S.K. 2012. The influence of pyrethrum extract on the developmental stages of the ricemoth, Corcyra cephalonica Stainton (Lepidoptera: Pyralidae). Egyptian Journal of Biology, 14: 57-62.

Singh, R. and Mishra, S.B. (1989). Insect pests of rice and paddy in storage and their control. Seeds and Farmers, 15: 16-19.

Singh, K.N. and Srivastava, P.K. (1980). Neem seed powder as a protectant against stored grain insect pest. Bulletin of Grain Technology, 18: 127-129.

Tillman, P.G. and Mulrooney, J.E. (2000). Effect of selected insecticides on the natural enemies Coleomegilla maculate and Hippodamia convergens (Coleoptera: Coc- cinellidae), Geocoris punctipes (Hemiptera: Lygaeidae) and Bracon mellitor, Cardiochiles nigriceps and Cotesia marginiventris (Hymenoptera: Braconidae) in cotton. Journal of Economic Entomology, 93: 1638-1643.

Tiwari, N. and Tiwari, S.N. (2008). Management of insect pests of stored grains by Diatomaceous earth formulation Insecto under Indian conditions. Pestology, XXXII.

Veeranki, S. and Reddy, K.D. (2004). Evaluation of various products of grain protectants against rice moth in maize. Journal of Research, ANGRAU, 32: 24-33.

Yadav, S.R.S. and Bhatnagar, K.N. (1987). A preliminary study on the protection of stored cowpea grain against pulse beetle by indigenous plant products. Pesticides, 21: 25-29.

Yadav, R., Yadav, N. and Yadav, R. (2011) ${ }^{\text {a }}$. Effect of botanical pesticides on the development of Corcyra cephalonica Stainton. Journal of Experimental Zoology, 14: 601-603.

Yadav, R., Srivastava, S.K., Yadav, N., Yadav, R. and Kumar, M. (2011) $)^{\mathrm{b}}$. Insecticidal properties of some natural pesticides against storage pest, Corcyra cephalonica. Journal of Experimental Zoology, 14: 259-260.

Zibokere, D.S. (1994). Insecticidal potency of red pepper (Capsicum annum) on pulse beetle (Callosobruchus maculates) infesting cowpea (Vigna unguiculata) seeds during storage. Indian Journal of Science, 64: 727-728. 